\title{
The Production of High Phycocyanin by Applications of Red Light-Emitting Diodes (LEDs) In Vitro Algae Growth on Spirulina platensis
}

\author{
Huynh Van-Hieu ${ }^{1}$, Luong Quang-Tuong², Bien Cong-Doan ${ }^{1}$ \\ ${ }^{1}$ Faculty of Biotechnology, Nguyen Tat Thanh University, Ho Chi Minh City, 70000, Vietnam \\ ${ }^{2}$ Faculty of Food and Environmental Engineering, Nguyen Tat Thanh University,
} Ho Chi Minh City, 70000, Vietnam

(Received 12 January 2021; revised manuscript received 18 June 2021; published online 25 June 2021)

\begin{abstract}
Spirulina platensis are cultured at a large scale around the world primarily for providing food supplements for human as well as animal diets. Various light-emitting diodes (LEDs) with different light wavelengths are conducted to explore the positive effects of light source on photoautotrophic cultivation of Spirulina platensis in this study. From the experimental results, red LED $\lambda_{\max }=632 \mathrm{~nm}$ exhibits the highest specific growth rate under continuous illumination $\left(192,5 \mu \mathrm{mol} \mathrm{m}^{-2} \mathrm{~s}^{-1}\right)$. Among them, red LED light in experiment 2 is determined as the best light for biomass and phycocyanin, results present that algae grew up to the $7^{\text {th }}$ day and then the maximum density of biomass was $1.231 \pm 0.0005 \mathrm{~g} \mathrm{~L}^{-1}$, this developed cultivation takes 9 days, yielding $3.54 \mathrm{mg} \mathrm{mL}-1$ C-phycocyanin with a purity of 2.0 gram from Spirulina platensis, followed by red LED in experiment 1, red LED in experiment 3 and white LED in control. This result is proposed to fit the specific growth rates of Spirulina platensis and high C-phycocyanin from red LED $\lambda_{\max }=632 \mathrm{~nm}$ in the experiment 2 to determine this wavelength being important for algae growth with high C-phycocyanin. Hence, the information LEDS about the biopotential of this attractive alga for industrial application needs further research.
\end{abstract}

Keywords: LEDs, Algae growth, Spirulina platensis.

DOI: 10.21272/jnep.13(3).03034

PACS number: 85.60.Jb

\section{INTRODUCTION}

Spirulina platensis is a photosynthetic bacterium, having high-value compounds as phycocyanin, proteins that can be applied in bioremediation and the food sectors in animal and human feeding. Spirulina platensis is cultivated in open ponds utilizing solar energy which is the most cost-effective energy source for industrial applications. This cultivation system is expansive and needs large areas of land which land is not available or even limited. In practice, artificial illumination will be of choice in converting the cultivation system into an intensive one in small areas. Light quality effects the growth as well as biochemical properties of photosynthetic microalgae. There are various light sources, such as solar light [1], fluorescent lamps (FLs) [2], lightemitting diodes (LEDs) [3, 4], have been used to produce the biomass and valuable biochemical components[5]. These light sources give information on the effects of wavelength and light intensity on microalgal growth and cell division in the culture system. Photosynthetic microorganisms do not utilize the whole solar spectrum, just a fraction of it and the artificial lighting may be energetically efficient in an intensive one, Spirulina platensis may be cultivated in small wetland [6]. The main cons of the artificial lighting against sunlight are as higher initial construction costs and high energy consumption to drive the artificial lighting in whole system. In advanced LED technology, LEDs are considered an attractive artificial light in microalgae production systems [1], it is easy to control the photosynthetic photon flux density and photoperiod, LEDs also have narrow band wavelength and low power consumption for industrial applications[3]. First and foremost, the kind of relationship between biomass growth and pigment synthesis must be defined for each case, as a func- tion of microalgal physiology and operational conditions in intensive system [5]. This information is crucially important for the overall research strategy to minimize the experiments required to achieve the desired goals in selecting LEDs. It has attracted attention for a cultural time due to its relative fast growth, commercial cultivation potential, higher photosynthetic efficiency and locating in small-scale areas [7]. Hence, the objective of this research was to determine the different wavelengths of red LEDs affecting Spirulina platensis biomass and identify the different wavelengths of red LEDs that affect the C-phycocyanin content.

\section{EXPERIMENT}

\subsection{Microorganism and Culture Conditions}

Spirulina platensis used in the study is obtained from the College of Natural Sciences, Ho Chi Minh City, Vietnam. The algae density is $0.5 \mathrm{~g} / 5 \mathrm{~L}^{-1}$. The experiments in Fig. 1 are performed by the cultivation of Spirulina platensis in Zarrouk medium with the following composition ( $\left.\mathrm{L}^{-1}\right)$ : $16.8 \mathrm{~g} \mathrm{NaHCO} 3,2.5 \mathrm{~g}$ $\mathrm{NaNO}_{3}, 0.5 \mathrm{~g} \mathrm{~K}_{2} \mathrm{HPO}_{4}, 1.0 \mathrm{~g} \mathrm{~K}_{2} \mathrm{SO}_{4}, 1.0 \mathrm{~g} \mathrm{NaCl}, 0.04 \mathrm{~g}$ $\mathrm{CaCl}_{2}, 0.08 \mathrm{~g}$ Na 2 EDTA, $0.2 \mathrm{~g} \mathrm{MgSO}_{4} \cdot 7 \mathrm{H}_{2} \mathrm{O}, 0.01 \mathrm{~g}$ $\mathrm{FeSO}_{4} \cdot 7 \mathrm{H}_{2} \mathrm{O}$, and $1.0 \mathrm{~mL}$ of trace elements $\left(\mathrm{l}^{-1}\right): 2.86 \mathrm{~g}$ $\mathrm{H}_{3} \mathrm{BO}_{3}, 0.02 \mathrm{~g}\left(\mathrm{NH}_{4}\right) 6 \mathrm{Mo}_{7} \mathrm{O}_{24}, 1.8 \mathrm{~g} \mathrm{MnCl}_{2} \cdot 4 \mathrm{H}_{2} \mathrm{O}, 0.08 \mathrm{~g}$ $\mathrm{Cu}_{2} \mathrm{SO}_{4}$, and $0.22 \mathrm{~g} \mathrm{ZnSO}_{4} \cdot 7 \mathrm{H}_{2} \mathrm{O}$. The cultivation is conducted in continuous mode without the dilution rate. The cultivation in Fig. 1 is carried out in plastic container containing 30 liters of Zarrouk medium for 9 days. The interior of the container is equipped aerator tube as aquarium, LEDs are fixed in the top of the plastic container. Four experiments in Fig. 2 of Spirulina platensis in photo-stimulation performs with replicates to reproduce the best conditions found. 


\begin{tabular}{ccc}
\hline $\begin{array}{l}\text { Description } \\
\text { LEDs }\end{array}$ & \multicolumn{3}{c}{ Experimental design } \\
\hline $\begin{array}{c}\text { Control } \\
\text { White LED light, } \\
\lambda_{\max }=454 \mathrm{~nm}\end{array}$ \\
\hline $\begin{array}{c}\text { Experiment 1 } \\
\text { LED light } 2835-96 \mathrm{D}, \\
\lambda_{\max }=621 \mathrm{~nm}\end{array}$ \\
\hline $\begin{array}{c}\text { Experiment 2 } \\
\text { Rang Dong LED } \\
\text { lights, } \\
\lambda_{\max }=632 \mathrm{~nm}\end{array}$ \\
$\begin{array}{c}\text { Experiment 3 } \\
\text { LED lamp 5050-60D, } \\
\lambda_{\max }=635 \mathrm{~nm}\end{array}$ \\
\hline
\end{tabular}

Fig. 1-Peak wavelength emission from the various LED colors used in 9 days

Using LEDs, and particularly paying attention to their color composition when growing Spirulina platensis cultures [8]. Report [9] shows the physical and spectral characteristics of light emitting diodes, the main band (nm) of white LED: 380-760, the main band (nm) of red LED: 620-635.

\subsection{Samples Collection and Analysis}

The biomass of Spirulina platensis is determined by taking $30 \mathrm{~mL}$ of filter algae on whatman filter paper, put in dried machine to constant value, taken to balance to determine the final biomass of Spirulina platensis. The cultures of Spirulina platensis are monitored visually using a microscope. Biomass production is determined in triplicate $(n=3)$. Mean values and standard errors of value are calculated from replicates (mean \pm S.E, $n=3$ ).

Method of extraction of C-phycocyanin (C-PC) with water [10,11], the phycocyanin content of the Spirulina platensis is assayed according to steps. Firstly, the biomass of the $5 \mathrm{~mL}$ sample was centrifuged $(10,000 \times \mathrm{g}$, $\left.15 \mathrm{~min}, 4^{\circ} \mathrm{C}\right)$. The pellet is mixed with $5 \mathrm{~mL}$ of $0.05 \mathrm{M}$ sodium phosphate buffer with a $\mathrm{pH}$ of 7.0 and then homogenized. The cell debris is reduced by centrifugation at $10,000 \times \mathrm{g}$, and the supernatant (blue color) is taken.

The absorbance of crude extract is calculated with a UV/vis spectrophotometer at 620 and $652 \mathrm{~nm}$. Finally, the C-PC content is estimated according to the belove equation [12]:

$$
\mathrm{C}-\mathrm{PC}\left(\mathrm{gL}^{-1}\right)=\mathrm{OD}_{620}-0.474 \cdot \mathrm{OD}_{650} / 5.34 \text {. }
$$

\section{RESULTS AND DISCUSSION}

Control

White LED $\lambda_{\max }=454 \mathrm{~nm}$

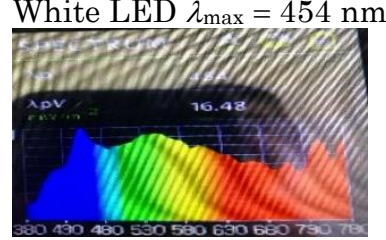

\subsection{The Growth Performance of Spirulina platensis}

The water temperature in this study ranges from $26.0 \pm 0.0{ }^{\circ} \mathrm{C}$ to $28.35 \pm 0.23^{\circ} \mathrm{C}$ with an average $27.5 \pm$ $0.77^{\circ} \mathrm{C}$. The average $\mathrm{pH}$ value records for this study 9.3 \pm 0.38 and the $\mathrm{pH}$ concentration of range is from $8.7 \pm$ 0.29 to $9.75 \pm 0.23$. Cell growth (biomass concentration curve) of Spirulina platensis in plastic container culture of 30 liters, over 9 days under optimal growth conditions (Zarrouk medium) is depicted in Fig. 3 in an increase of the biomass of Spirulina platensis in all four experiments as following:

- Control of white LED light with $\lambda_{\max }=454 \mathrm{~nm}$ under continuous illumination $\left(16,48 \mu \mathrm{mol} \mathrm{m} \mathrm{m}^{-2} \mathrm{~s}^{-1}\right)$. Algae grew up to the $8^{\text {th }}$ day and then the maximum density of biomass was $1.101 \pm 0.0005 \mathrm{~g} \mathrm{~L}^{-1}$.

- Experiment 1 of red LED light with $\lambda_{\max }=621 \mathrm{~nm}$ under continuous illumination $\left(409,8 \mu \mathrm{mol} \mathrm{m} \mathrm{m}^{-2} \mathrm{~s}^{-1}\right)$. Algae grew up to the $6^{\text {th }}$ day and then the maximum density of biomass was $1.132 \pm 0.0 \mathrm{~g} \mathrm{~L}^{-1}$.

- Experiment 2 of red LED light with $\lambda_{\max }=632 \mathrm{~nm}$ under continuous illumination $\left(192,5 \mu \mathrm{mol} \mathrm{m} \mathrm{m}^{-2} \mathrm{~s}^{-1}\right)$. Algae grew up to the $7^{\text {th }}$ day and then the maximum density of biomass was $1.231 \pm 0.0005 \mathrm{~g} \mathrm{~L}^{-1}$.

- Experiment 3 of red LED light with $\lambda_{\max }=635 \mathrm{~nm}$ under continuous illumination $\left(1186 \mu \mathrm{mol} \mathrm{m} \mathrm{m}^{-2} \mathrm{~s}^{-1}\right)$. Algae grew up to the $7^{\text {th }}$ day and then the maximum density of biomass was $1.010 \pm 0.0005 \mathrm{~g} \mathrm{~L}^{-1}$.

Report [7] provides the multiple stress factors applied to the adopted culture process could be a promising strategy to produce biomass enriched in various high-value compound. A higher specific Chl production rate accompanied by a higher $S$. platensis biomass is obtained in this report [13]. The different biomass shows that the different light wavelength seems one of the driving factors microalgae production in Zarrouk medium. These LEDS also effect on morphology of Spirulina platensis and the estimated composition is similar that reported cell morphologies in Zarrouk medium under microscope in the Fig. 4. Under these conditions, the maximum density of biomass the exponential growth phase was observed from the $2^{\text {nd }}$ day to the $5^{\text {th }}$ day of culture in all experiments, but the biomass of the experiment 1, 2 were higher than the control and the experiment 3. Dynamic changes by various wave lengths in metabolic pathways occurred, to augment the cell thriving in different value in Fig. 4. Main point may be the effect of light intensity on metabolite content of microalgae was regulated by the photo-acclimatization process, support the maximum specific growth rate in the experiment 1 of red LED light with $\lambda_{\max }=621 \mathrm{~nm}$ and the experiment 2 of red LED light with $\lambda_{\max }=632 \mathrm{~nm}$. Despite widespread use of artificial light in microalgae studies, artificial light has the critical dis-
Experiment 2

Red LED $\lambda_{\max }=632 \mathrm{~nm}$

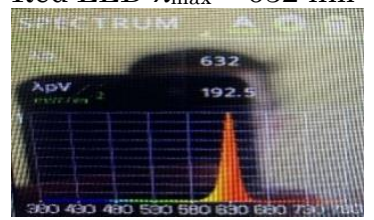

Experiment 3

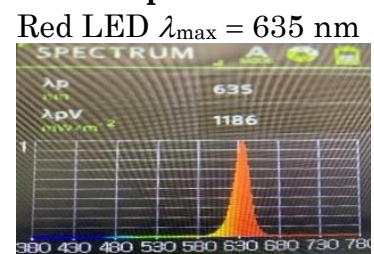

Fig. 2 - Emission spectra for different LEDs by Spectrometer UPRTEK 
advantage of releasing heat inside or outside of the photobioreactor depending on the location of the light $[5,14]$. The increase in microalgae at high light intensities was considered as energy storage to adjust their growth under changing environmental light conditions. According to our data, maxima of red LED exposure to high light intensity make the negative effect, for examples, Fig. 4 showed that this biomass and microalgae cell morphologies under microscope of experiment 3 of red LED $\lambda_{\max }=635 \mathrm{~nm}$ under continuous illumination $\left(1186 \mu \mathrm{mol} \mathrm{m}{ }^{-2} \mathrm{~s}^{-1}\right)$ is lower than the experiment 1,2 .

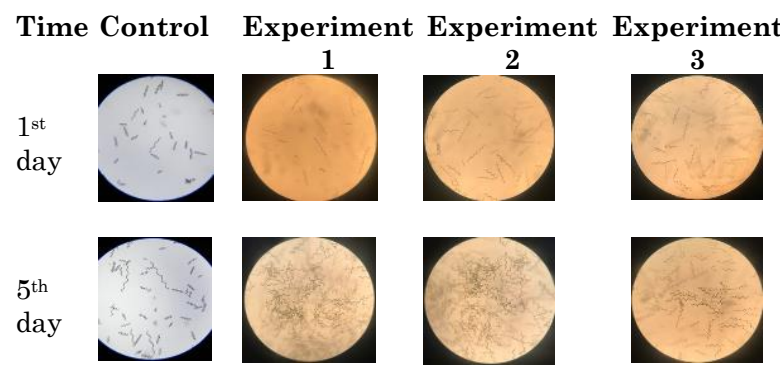

Fig. 3-Time course of Spirulina platensis growth and cell morphologies under microscope

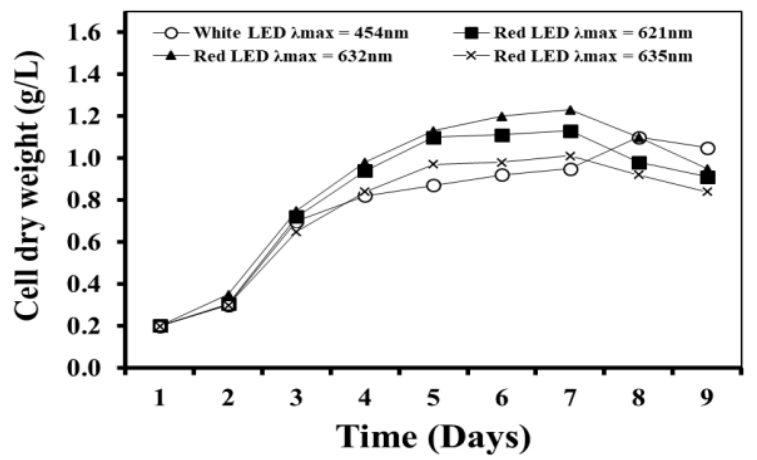

Fig. 4-Growth of Spirulina platensis biomass over time under various light sources

This previous data observes red wavelengths promote the synthesis of C-PC in $2 \mathrm{~g}$ of dry algae. C-PC extract from Rang Dong LED lights with a wavelength of $632 \mathrm{~nm}$ was $3.54 \mathrm{mg} \mathrm{mL}-1$ higher than $2.83 \mathrm{mg} \mathrm{mL}^{-1}$

\section{REFERENCES}

1. M. Cuaresma, M. Janssen, C. Vílchez, R.H. Wijffels, Biotechnol. Bioeng. 104 No 2, 352 (2009).

2. S.K. Yim, D.W. Ki, H.S. Doo, H. Kim, T.H. Kwon, Biotechnol. Bioprocess Eng. 21 No 6, 767 (2016).

3. Y. Zhong, P. Jin, J.J. Cheng, Planta. 248 No 2, 489 (2018).

4. Jihae Park, Dinh Thai Binh, Bioresour Technol. 291, 121846 (2019).

5. V.D. Gonçalves, Márcia Regina Fagundes-Klen, Daniela Estelita Goes Trigueros, Adilson Ricken Schuelter, Alexander Dimitrov Kroumov ANM, Algal Res. 101649 (2019).

6. N.T.T. Nhan, L.Q. Tuong, IOP Conf. Ser.: Mater. Sci. Eng. 991, 012034 (2020).

7. I. Chentir, A. Doumandji, J. Ammar, et al., J. Appl. Phycol. 30 No 3, 1563 (2018).

8. Gustavo M. Lima, Pedro C.N. Teixeira, Cláudia M.L.L. Teixeira, Diego Filócomo, Algal Res. 31, 157 (2018). of red LED light 2835-96D, wavelength $621 \mathrm{~nm}$. Report [15] presents that C-phycocyanin (C-PC) produced from Spirulina platensis seems of great commercial interest due to its healthcare properties once fresh biomass is suitable for phycocyanin extraction. C-phycocyanin (CPC) produced from Spirulina platensis may be of great commercial interest due to its healthcare properties [15].

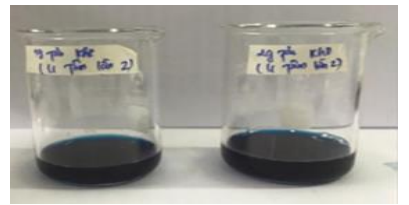

A) C-phycocyanin collected after extraction process

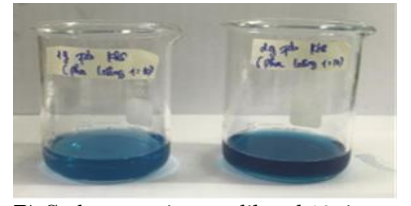

B) C-phycocyanin was diluted 10 times
Fig. 5 - Final extraction and purification of C-phycocyanin from Spirulina platensis

\section{CONCLUSIONS}

Results confirm that the green microalgae exhibit different performance of maximum growth rate and different biomass by using LEDs. Application of red LED to microalgal cultivation increased both the maximum specific growth rate, photosynthetic pigments and C-phycocyanin (C-PC). Red LED light is effective for algae growth, being $\lambda_{\max }=621 \mathrm{~nm}$ and $\lambda_{\max }=632 \mathrm{~nm}$. It is the first report on measuring the effects of simple red LED light on cultured development of Spirulina platensis. The red LED with a wavelength $\lambda_{\max }=632 \mathrm{~nm}$ is the best light source for higher phycocyanin productivity than the red LED with a wavelength $\lambda_{\max }=621 \mathrm{~nm}$ because this cultivation developed took 9 days, yielding $3.54 \mathrm{mg} \mathrm{mL}^{-1} \mathrm{C}-\mathrm{PC}$ with a purity of 2.0 gram from Spirulina platensis. To conclude, the results indicates that the red LED $\lambda_{\max }=632 \mathrm{~nm}$ will be used in growth on Spirulina platensis to produce of high phycocyanin with a great potential for human nutrition supplement and biofuel production.

\section{ACKNOWLEDGEMENTS}

This research is funded by Nguyen Tat Thanh University, Ho Chi Minh city, Vietnam.

9. Ankita Kumari, Akhilendra K. Pathak, Chandan Guria, Phycol. Res. 63, 274 (2015).

10. S.T. Silveira, J.F.M. Burkert, J.A.V. Costa, C.A.V. Burkert, S.J. Kalil, Bioresour. Technol. 98, 1629 (2007).

11. R. Sarada, G. Manoj, G.A.R. Pillai, Process Biochem. 34, 795 (1999).

12. C.T. Brandt, L.J. Rothbarth, D. Kumpe, F.M. Karrer, J.R. Lilly, J. Cell Biol. 58, 419 (1973).

13. H.B. Chen, J.Y. Wu, C.F. Wang, et al., Biochem. Eng. J. 53 No 1, 52 (2010).

14. P.S.C. Schulze, L.A. Barreira, H.G.C. Pereira, J.A. Perales, J.C.S. Varela, Trend. Biotechnol. 32 No 8, 422 (2014).

15. S.H. Ho, J.F. Liao, C.Y. Chen, J.S. Chang, Bioresour. Technol. 247, 669 (2018). 


\title{
Виробництво фікоціаніну високої чистоти шляхом застосування червоних світлодіодів (LEDs) при зростанні водоростей Spirulina platensis
}

\author{
Huynh Van-Hieu ${ }^{1}$, Luong Quang-Tuong², Bien Cong-Doan ${ }^{1}$ \\ ${ }^{1}$ Faculty of Biotechnology, Nguyen Tat Thanh University, 70000 Ho Chi Minh City, Vietnam \\ ${ }^{2}$ Faculty of Food and Environmental Engineering, Nguyen Tat Thanh University, \\ 70000 Ho Chi Minh City, Vietnam
}

\begin{abstract}
Spirulina platensis культивуеться у великих масштабах по всьому світу, в першу чергу для забезпечення харчових добавок як для людей, так і для тварин. Для вивчення позитивного впливу джерела світла на фротоаутотрофрне культивування Spirulina platensis у цьому дослідженні використовуються різні світлодіоди (LEDs) з різною довжиною хвилі світла. 3 експериментальних результатів випливає, що використання червоного LED з $\lambda_{\max }=632$ нм призводить до найвищої питомої швидкості росту Spirulina platensis при постійному освітленні (192,5 мкмоль $\left.\mathrm{M}^{-2} \cdot \mathrm{c}^{-1}\right)$. Світло від LED в експерименті 2 визначено найкращим світлом для біомаси та фікоціаніну. Результати показують, що водорості росли до 7-го дня, а потім максимальна густина біомаси становила 1,231 $\pm 0,0005$ г·л ${ }^{-1}$. Розвинене культивування займае 9 днів, даючи 3,54 мг·мл-1 C-рікоціаніну із Spirulina platensis з чистотою 2,0 г, для чого після LED в експерименті 2 включали червоний LED в експерименті 1 , далі червоний LED в експерименті 3 і білий LED в контрольному експерименті. Передбачається, що цей результат відповідає питомій швидкості росту Spirulina platensis i C-фікоціаніну високої чистоти від червоного LED з $\lambda_{\max }=632$ нм в експерименті 2 , щоб довести, що ця довжина хвилі важлива для зростання водоростей з вмістом С-фрікоціаніну високої чистоти. Отже, питання про біопотенціал цієї привабливої для промислового застосування водорості потребуе подальшого вивчення.
\end{abstract}

Ключові слова: Світлодіоди (LEDs), Ріст водоростей, Spirulina platensis. 